J. Environ. Sci.

Institute of Environmental Studies and Research - Ain Shams University

\title{
IMPACT OF HIKING TRAIL DISTURBANCE ON ANTS DIVERSITY AT MOUNT SINAI, ST. KATHERINE PROTECTORATE, EGYPT
}

\author{
Mohamed, Kamel $^{(1)}$; Fayez, M. Semida ${ }^{(2)}$; Mohamed, M. S. Moursy ${ }^{(3)}$ \\ and Hala, A. Kassem ${ }^{(1)}$
}

1) Department of Basic Science, Institute of Environmental Studies and Research, Ain Shams University 2) Department of Zoology, Faculty of Science, Suez Canal University 3) Department of Botany and Microbiology, Faculty of Science, Al Azhar University

\begin{abstract}
Saint Katherine Protectorate (SKP) is one of the most important regions for biodiversity in Egypt. Tourism and its associated activities has become the main economic driver in SKP which might have negative impacts on biodiversity. Ants are effective biological indicators, since ant species diversity correlates with the assembly of other invertebrate fauna of particular habitats. The current study aimed at assessing the impact of some anthropogenic activities along the touristic hiking trail passing through Mount Sinai area on ants diversity. A total of 583 individuals belonging to nine ant species, three subfamilies, from (Family: Formicidae; Order: Hymenoptera) were recorded within the study localities in Mount Sinai. Our study showed that the hiking trail disturbance had a negative environmental impact on the species richness and abundance of ants within the study localities in Mount Sinai. Based on our results it is advisable to move the hiking trails to slopes of Mount Sinai away from its current location within the basins (farshs). More studies are needed to assess the impact of hiking trails and associated human activities on other biodiversity elements in SKP.
\end{abstract}

Keywords: Biodiversity, St Katherine, ant species, anthropogenic activities, tourism, Sinai, Egypt 


\section{INTRODUCTION}

St. Katherine Protectorate (SKP) is a unique area for biodiversity. The biological resources of Saint Katherine protectorate have an important economic value, and its biodiversity is of great scientific interest. It includes Egypt's highest mountains, which support a unique collection of high altitude ecosystems, with a high diverse fauna and flora (Baha El Din, 2006) and a relatively high representation of endemic species (St. Katherine protectorate management plan (SKP-M.P.), 2003).

Mount Sinai (Mousa Mountain) is considered one of the highest peaks of Egypt with an altitude $\simeq 2280 \mathrm{~m}$ above sea level (SKP-M.P., 2003). It contains the most important biodiversity rich spots in St. Katherine area such as Farsh Elias, Farsh El Losa, Farsh Shoeab and Farsh El Hemar. A major hiking trail about $2 \mathrm{~km}$ long passes through these spots and is used by tourists and local inhabitants during their visits to the area.

Protected areas as biodiversity standards allow a separation of the direct effects of human impact on biodiversity from those of other environmental changes (Sinclair et al., 2002). Accordingly, these regions present ideal systems for evaluating the impact of human activities. SKP faces severe threats to their conservation status (Fouda et al., 2006). Some threats are global such as climate change and international tourism, whilst others arise from local socio-economic issues and necessities (e.g. the over-harvesting of wild resources) (Grainger and Gilbert, 2008). Nature-based tourism and recreation activities such as hiking, wildlife viewing, and cycling within and close to protected areas might had negative impacts on animal communities 
and biodiversity within protected areas (Knight and Cole, 1995; Huhta and Sulkava, 2014). The use of hiking trails is one of the most important recreational activities that have widespread impacts on ecosystems (Queiroz et al., 2014).

Ants are effective biological indicators, since ant species diversity correlates with the assembly of other invertebrate fauna of particular habitats (Majer, 1983). Ants have been used as indicator species in a number of studies (Gollan et al., 2011; Schmidt et al., 2013; Fisher et al., 2014; Berberich et al., 2016). Ants are diverse and abundant in most ecosystems (Roth et al., 1994), and have a community structure that reflects the nature of the area in which they occur (Majer, 1983; Hoffmann, 2010; Gollan et al., 2011).

Although hiking trail is certainly less harmful than a road, it may have an impact on small invertebrates; even a narrow hiking trail could fragment their habitat. A maintained hiking trail could act as a barrier to dispersal of non-flying species (Mader, 1984). Kwon (2015) reported that the impact of trails on ants is complex, requires thorough research. Shepherd (2010) in her study in SKP about the role of ants in conservation of the sinai baton blue butterfly, found four ant species belonging to the subfamily Formicinae and three ant species belonging to the subfamily Myrmicinae in Farsh Shoeab only.

Accordingly, this study aimed at assessing the impact of some anthropogenic activities along the touristic trail passing through Mount Sinai area (Farsh Elias, Farsh El Losa, Farsh Shoeab and Farsh El Hemar) on ants` 
diversity. The study also aimed at identifying and quantifying ant species within the study localities in Mount Sinai.

\section{Study area:}

\section{MATERIALS AND METHODS}

St. Katherine protectorate expands over virtually the entire mountain massif of South Sinai with an area of $4,350 \mathrm{~km}^{2}$ (SKP-M.P. 2003). SKP is characterized by the highest mountains in Egypt and a dense Wadi system. It was declared as a protected area in 1996 due to its cultural and biological values (SKP-M.P. 2003). SKP is characterized by a Saharo-Mediterranean climate. Summers are relatively hot, and winters are relatively cold (SKP-M. P. 2003). Its arid climate with little rains in winter reflected as a unique flora and fauna (Semida, 2006). SKP is the coolest area in Sinai due to its high elevation (1500-2641 m above sea level). According to SKP weather station, the lowest monthly mean minimum temperature ranges between $4{ }^{\circ} \mathrm{C}$ and 10 ${ }^{\circ} \mathrm{C}$, while the highest monthly mean maximum temperature varies between 28 ${ }^{\circ} \mathrm{C}$ and $32{ }^{\circ} \mathrm{C}$. The mean temperatures ranged from $9{ }^{\circ} \mathrm{C}$ to $26.5{ }^{\circ} \mathrm{C}$ while mean monthly relative humidity ranging between 29.4 and $54.5 \%$. Annual precipitation for the 4-year period (2013-2016) averaged about $8 \mathrm{~mm}$, occurring mainly in January, February, March, and December.

SKP is one of the richest spots for flora diversity in the Middle East; from which $\simeq 472$ plant species have been recorded (Fayed and Shaltout, 2004). Twinty six endemic plant species were recorded in SKP which comprise $42.6 \%$ of Egypt endemic plant species. These endemic species were mainly located in four main mountains namely: St. Katherine Mountain, 
Serbal Mountain, Sinai (Musa) Mountain, and Umm Shaumer Mountain (Ramadan et al., 2009).

In this study, four localities namely, Farsh Elias, Farsh El Losa, Farsh Shoeab and Farsh El Hemar were selected for monitoring and sampling of ants`species in SKP (Table 1; Fig. 1\& 2).. These localities represent the main farshs (basins) above Mount Sinai. The vegetation structure among these localities was more or less the same.

Table 1: Geographic attributes of four study localities in Saint Katherine protectorate

\begin{tabular}{|c|c|c|c|}
\hline Locality & $\begin{array}{c}\text { Longitude } \\
\text { (North) }\end{array}$ & $\begin{array}{c}\text { Latitude } \\
\text { (East) }\end{array}$ & $\begin{array}{c}\text { Altitude (m) } \\
\text { Above sea level }\end{array}$ \\
\hline Farsh Elias & 28.5462 & 33.9742 & 2045 \\
\hline Farsh El Losa & 28.5487 & 33.9712 & 2000 \\
\hline Farsh Shoeab & 28.5526 & 33.9669 & 2014 \\
\hline Farsh El Hemar & 28.54646 & 33.96774 & 2030 \\
\hline
\end{tabular}




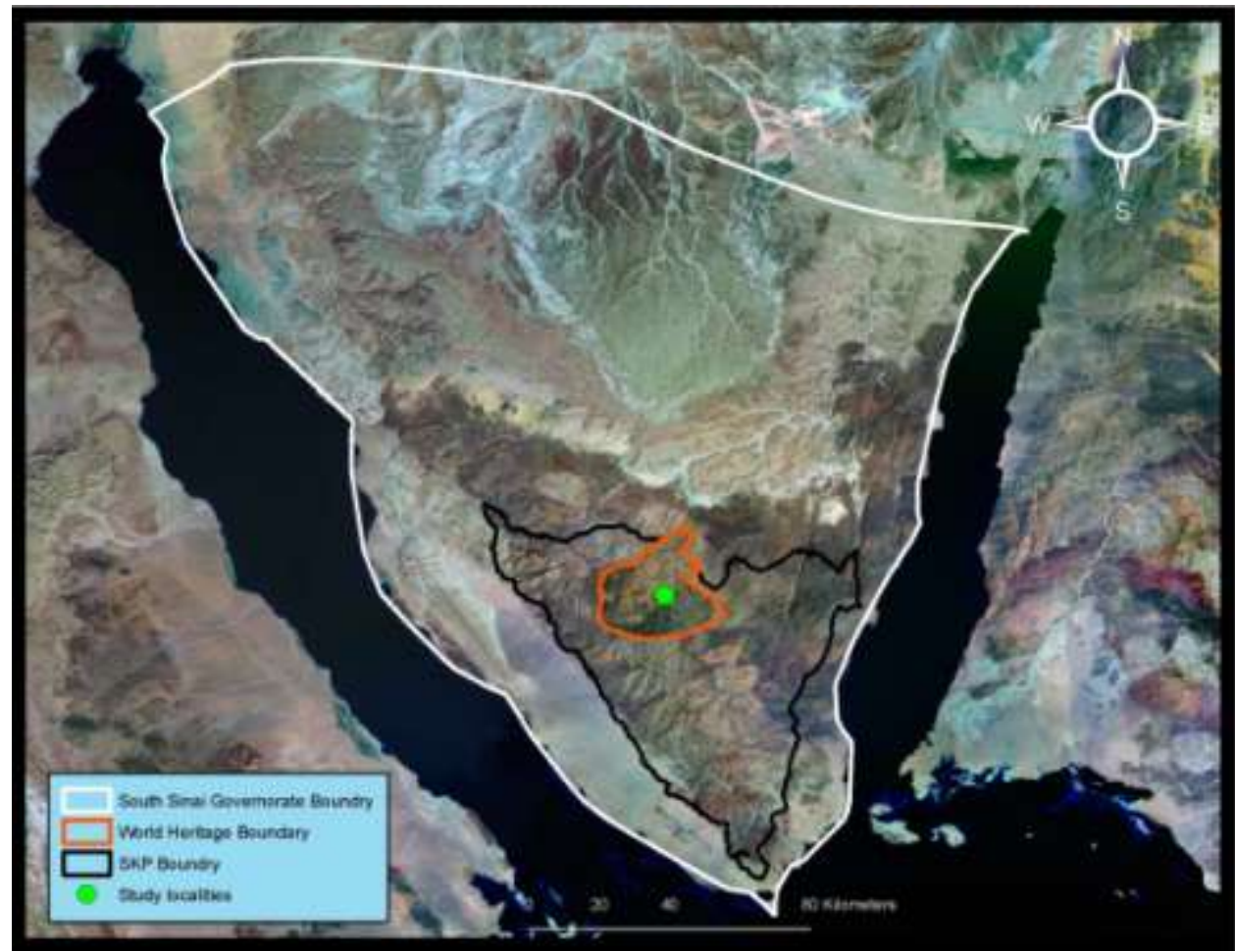

Fig. 1. Location map showing boundaries of South Sinai Governorate, World Heritage Site, and St. Katherine protectorate. (Map source: SKP, GIS unit \& google map -

https://www.google.com.eg/maps/@28.9319362,34.2174414,8z). 
J. Environ. Sci.

Institute of Environmental Studies and Research - Ain Shams University

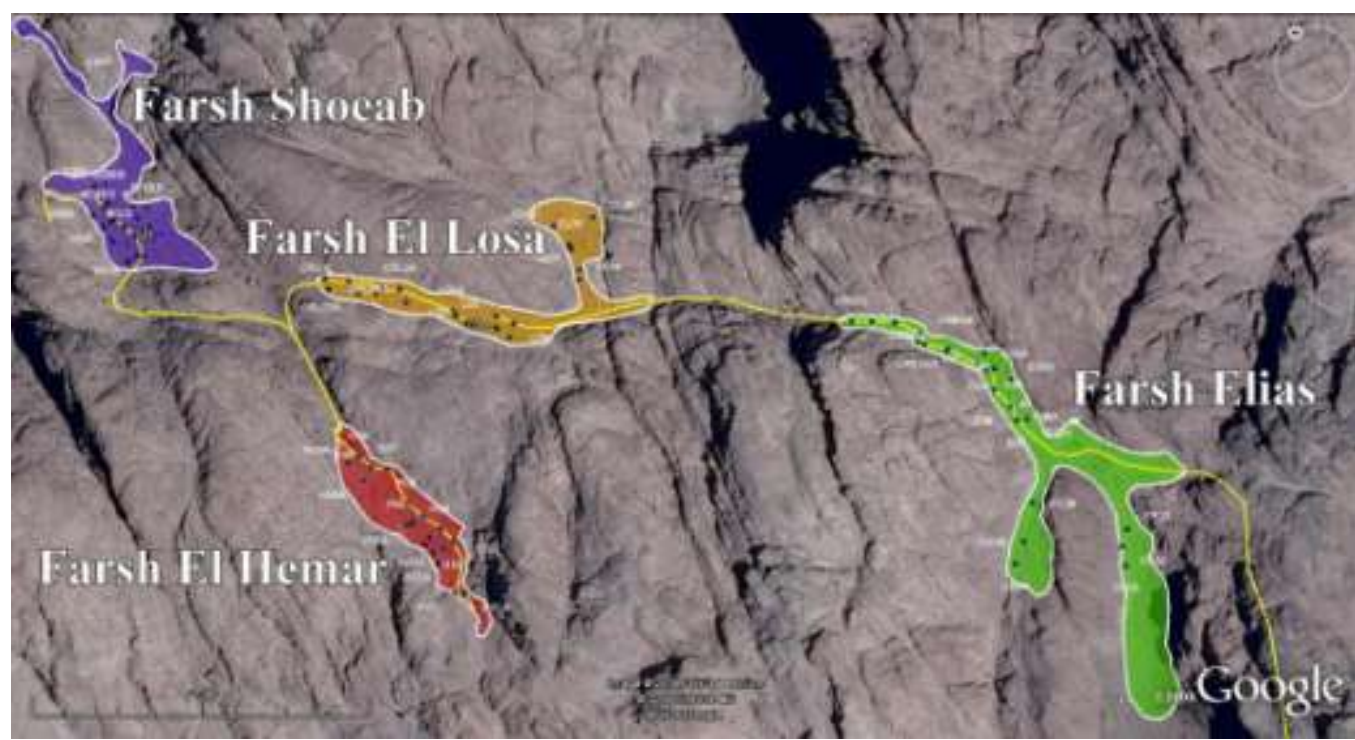

Fig. 2. Hiking trail passing through the four study localities. (.) Sampling points along the hiking trail

Map source: google map https://www.google.com.eg/maps/@28.5373631,33.977581,15z

\section{Monitoring and identification of ant species}

A bimonthly field survey started in January 2015 to December 2016. Each monitoring session spanned over six continuous days. To avoid a time bias for a particular monitoring site when recording ant species, each selected monitoring site was covered at different times of the day during the monitoring period.

Field monitoring of ant species across the touristic hiking trail passing through Mount Sinai area was carried out at different distances $(\simeq$ 0, 10, 20 m) along both sides of the hiking trail in Farsh Elias, Farsh El Losa, Farsh Shoeby and Farsh El Hemar (Fig. 2). As a control, monitoring was conducted at a distance of $150 \mathrm{~m}$ along both sides of the hiking trail. Ant species were 
sampled using pitfall traps. For identification of insect species, the collected samples were placed in a petri dish filled with an adequate amount of the fixative (10 parts of Formalin and 90 parts of Ethyl alcohol $60 \%$ ) to prevent sample dryness under examination. The manipulation of the samples was done under stereomicroscope (model МБС-9, USSR), using a fine forceps and a dissecting needle to prevent sample distortions. Ant species were identified using the key of Bolton (1994).

\section{Data analysis:}

Spatial variation of ant species in the study area was measured using species richness (S) and species evenness (E). Alpha diversity ( $\alpha$-diversity) within study localities was measured using Simpson`s diversity index, while beta diversity ( $\beta$-diversity) among study localities was measured using the Jaccard similarity index. Chi-square test of goodness-of-fit was used to determine whether the different ant species were equally distributed in the population within the study localities in Mount Sinai and to determine whether there was a significant difference, in ant species richness among the study localities in Mount Sinai. Spearman correlation test was used to measure the relation between species richness and abundance of ants and distance from the hiking trail for assessing the impact of hiking trail on ants species distribution within the study localities in Mount Sinai. Statistical analysis was carried out using SPSS computer package (ver.18, 2009). 
J. Environ. Sci.

Institute of Environmental Studies and Research - Ain Shams University

\section{RESULTS}

\section{Ants abundance and diversity in Mount Sinai:}

A total of 583 individuals belonging to nine ant species, three subfamilies, from (Family: Formicidae; Order: Hymenoptera) were recorded from January 2015 through December 2016.

Spatial variation in ants` diversity among the study localities was given in Table 2. Most species belonged to subfamily formicinae. However, highest number of individuals collected belonged to subfamily Myrmicinae. Total ant diversity in Mount Sinai was $0.754 \pm 0.007$. A high variation in Simpson diversity index (1- $\lambda$ ) was reported among the study localities in Mount Sinai. The highest diversity was recorded in Farsh Shoeab $(1-\lambda=0.645 \pm 0.015)$ and Farsh El Losa $(1-\lambda=0.579 \pm 0.025)$. The species richness recorded for these localities was seven and five, respectively. Lowest diversity was recorded in Farsh Elias $(1-\lambda=0.409 \pm 0.066)$ and Farsh El Hemar $(1-\lambda=0.312 \pm 0.052)$. The species richness recorded for these localities was four and five, respectively.

Spatial distribution of ant species among the four study localities was given in Table 3; Fig. $3 \& 4$. Chi-square test of goodness-of-fit revealed that ant species were not equally distributed among the four study localities where an overall significant difference in ant species distribution among the study localities was recorded $\left(\chi^{2}=712.40, \mathrm{df}=8, P<0.05\right)$. The most dominant ant species in the study area was Monomorium venustum. Ant species distribution within each locality varied significantly. There was a significant difference in the ant species distribution in the population within Farsh El Hemar, $\left(\chi^{2}=\right.$ 306.320, df $=4, P<0.05)$, Farsh Shoeab $\left(\chi^{2}=416.399\right.$, df $\left.=6, P<0.05\right)$, 
Farsh El Losa $\left(\chi^{2}=102.333, \mathrm{df}=4, P<0.05\right)$ and Farsh Elias $\left(\chi^{2}=75.333\right.$, df $=3, P<0.05)$. The most dominant ant species was Crematogaster aegyptiaca in Farsh El Hemar, Crematogaster antaris and Monomorium venustum in Farsh Shoeab, Monomorium venustum and Crematogaster aegyptiaca in Farsh El Losa, and Lepisiota hirsute in Farsh Elias.

There was also no significant difference, in ant species richness among the four localities (Farsh El Hemar, Farsh Shoeab, Farsh El Losa, and Farsh Elias) in Mount Sinai $\left(\chi^{2}=0.90, \mathrm{df}=3, P=0.843\right)$.

Table 2. Spatial variations in the ants' diversity (measured by Simpson's diversity index, species richness, and species evenness), within the study localities.

\begin{tabular}{||c|c|c|c|}
\hline localities & $\begin{array}{c}\text { Species } \\
\text { Richness (S) }\end{array}$ & $\begin{array}{c}\text { Simpson diversity } \\
\text { index (1- } \boldsymbol{\lambda})\end{array}$ & $\begin{array}{c}\text { Species } \\
\text { Evenness(E) }\end{array}$ \\
\hline \hline Farsh El Hemar & 5 & $0.312 \pm 0.052$ & 0.415 \\
\hline Farsh Shoeab & 7 & $0.645 \pm 0.015$ & 0.633 \\
\hline Farsh El Losa & 5 & $0.579 \pm 0.025$ & 0.619 \\
\hline Farsh Elias & 4 & $0.409 \pm 0.066$ & 0.508 \\
\hline Study area (overall) & 9 & $0.754 \pm 0.007$ & 0.705 \\
\hline
\end{tabular}

Table 3. Spatial distribution of the ant species within the study localities in Mount Sinai.

\begin{tabular}{||l|l|l|l|l|l|}
\hline \multirow{2}{*}{ The ant species } & \multirow{2}{*}{ Subfamily } & \multicolumn{4}{|l|}{ Number of individuals } \\
\cline { 3 - 6 } & & $\begin{array}{l}\text { Farsh } \\
\text { EI } \\
\text { Hemar }\end{array}$ & $\begin{array}{l}\text { Farsh } \\
\text { Shoeab }\end{array}$ & $\begin{array}{l}\text { Farsh } \\
\text { El Losa }\end{array}$ & $\begin{array}{l}\text { Farsh } \\
\text { Elias }\end{array}$ \\
\hline \hline Camponotus fellah & Formicinae & 0 & 2 & 0 & 0 \\
\hline Cataglyphis franchettii & Formicinae & 6 & 2 & 0 & 0 \\
\hline Crematogaster aegyptiaca & Myrmicinae & 103 & 6 & 41 & 0 \\
\hline Crematogaster antaris & Myrmicinae & 4 & 131 & 0 & 1 \\
\hline Lepisiota gracilicornis & Formicinae & 1 & 20 & 2 & 1 \\
\hline Lepisiota hirsuta & Formicinae & 0 & 22 & 0 & 40 \\
\hline Lepisiota obtusa & Formicinae & 0 & 0 & 2 & 0 \\
\hline Monomorium venustum. & Myrmicinae & 11 & 131 & 42 & 12 \\
\hline Tapinoma simrothi & Dolichoderinae & 0 & 0 & 3 & 0 \\
\hline \hline
\end{tabular}


J. Environ. Sci.

Institute of Environmental Studies and Research - Ain Shams University

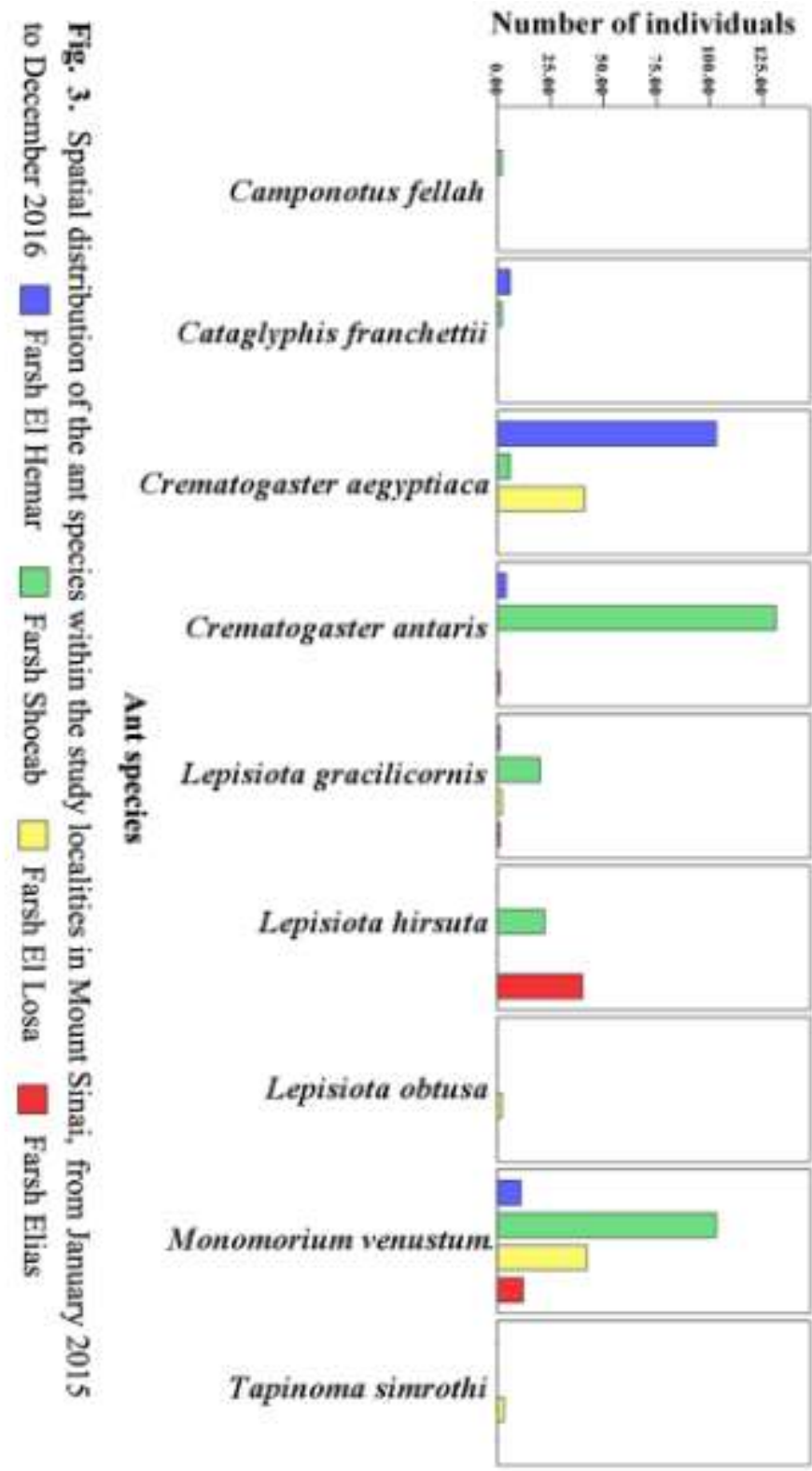

Vol. 45, No.1, Mar. 2019 


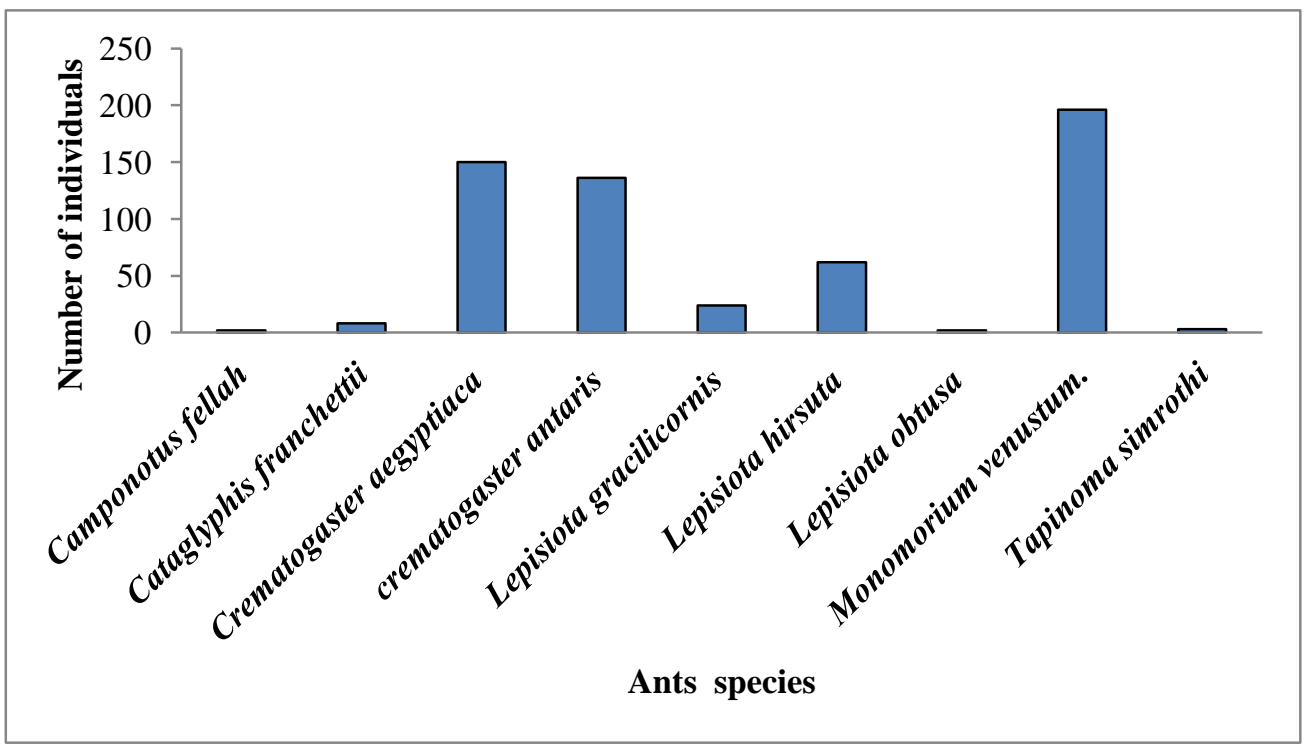

Fig. 4. Overall abundance of the ant species collected from the study localities in Mount Sinai.

2. Impact of hiking trail disturbance on the ant species richness and abundance distribution within the study localities in Mount Sinai

Ant species richness along the hiking trail was significantly positively correlated to the distance from the hiking trail $\left(\mathrm{r}_{\mathrm{s}}=0.475, P<0.01\right)$. Highest ants' species richness was recorded at $150 \mathrm{~m}$ from the hiking trail $(\mathrm{S}=5)$, and the ants' species richness recorded at $0 \mathrm{~m}, 10 \mathrm{~m}$ and $20 \mathrm{~m}$ was two, three, and four species, respectively (Fig. 5). Abundance of ant species along the hiking trail was significantly positively correlated to the distance from the hiking trail $\left(\mathrm{r}_{\mathrm{s}}=0.087, P<0.05\right)$. The highest ants' abundance was recorded at 150 $\mathrm{m}$ from the hiking trail (170 individuals), and the ants' abundance recorded at $0 \mathrm{~m}, 10 \mathrm{~m}$ and $20 \mathrm{~m}$ were 106, 150, and 129 individuals, respectively (Fig. $6)$. 
J. Environ. Sci.

Institute of Environmental Studies and Research - Ain Shams University

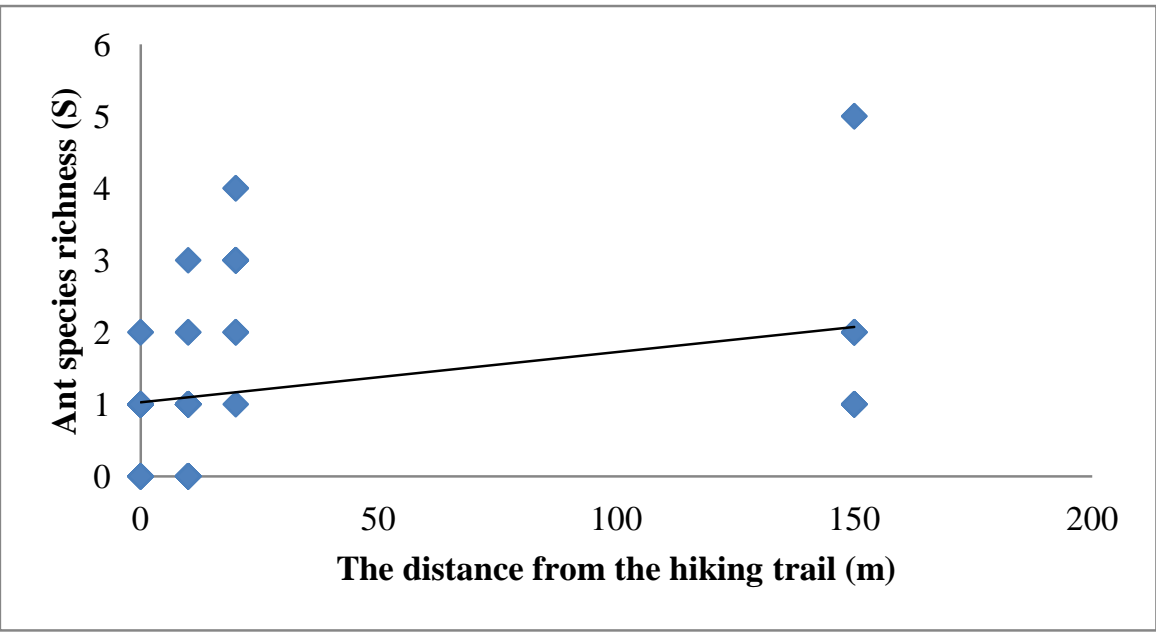

Fig. 5. The relationship between the distance from the hiking trail and the number of the ants' species richness within the study localities in Mount Sinai.

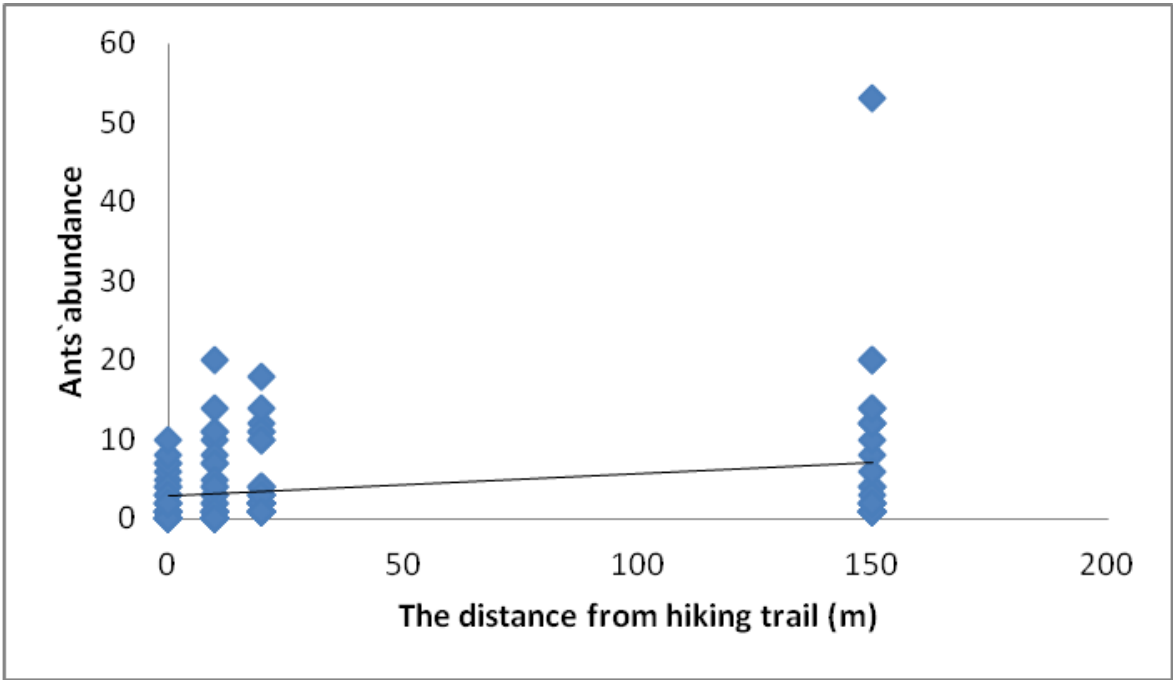

Fig. 6. The relationship between the distance from the hiking trail and the ants' abundance within the study localities in Mount Sinai. 


\section{Similarity indices of ant species composition between study localities.}

Similarity index of ant species composition sites was calculated using Jaccard similarity index and given in Fig.7. Highest Jaccard similarity coefficients were observed between Farsh El Hemar and Farsh Shoeab (0.714), followed by Farsh El Hemar and Farsh Elias (0.536), followed by Farsh El Hemar and Farsh El Losa (0.349). The overall similarity ratio among communities was $71.8 \%$.

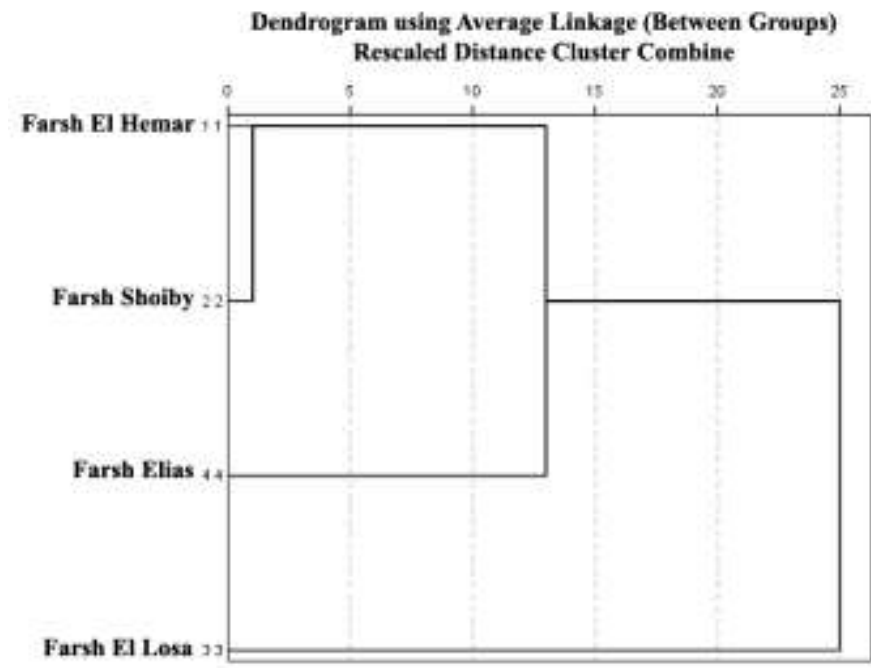

Fig. 7. Hierarchical cluster analysis of the study localities in Mount Sinai according to the type of the ants' species in each locality.

\section{DISCUSSION}

One of the most important challenges facing conservation biology was the increased human impacts on biodiversity hotspots (Zafra-Calvo et al., 2010). Land use modifications are responsible for loss of biodiversity (Michelsen et al., 2014). Species richness is used to assess the impact of habitat changing on biodiversity (Barragan et al., 2011; Michelsen et al., 
2014) and human impacts may cause a strong effect on species richness and diversity patterns (Petraitis et al., 1989). Generally, species richness is declining when human impacts increase at a local scale (Pautasso, 2007).

In this study, hiking trail passing through the four study localities (Farsh El Hemar, Farsh Shoeab, Farsh El Losa and Frash Elias) negatively impacted the species richness and abundance of ants in Mount Sinai as revealed by the positive correlation between the species richness and abundance of ants and the distance from the hiking trail within the study localities in Mount Sinai. This might be attributed to the increased mortality of ants by hikers on hiking trails. Similar results were obtained by Gray and Jongepier (2012) who reported a decrease in arthropod species diversity with an increase in human disturbance at Kirindy Forest, Western Madagascar. Hiking trails usage had negative impacts on insect populations, where hiking trail acts as a barrier to dispersal of non-flying species (Mader, 1984; Ciach et al., 2017). Contrary to that, Kwon (2015) found that high ant abundance were observed towards the trail and less population tended to be located further from the trails. $\mathrm{He}$ related his finding to the effect of the high humidity level found further away from the trail and the low competition among ant species near trails on ant abundance.

Total ants' diversity among the study localities was $0.754 \pm 0.007$ reflecting the high diversity of the ant species in Mount Sinai. The highest ants' diversity and species richness were recorded in Farsh Shoeab. The highest Jaccard similarity coefficients were observed between Farsh El Hemar and Farsh Shoeab. This might be due to the common occurrence of five ant species in both localities. In addition, the high similarity in vegetation 
structure and other physical environmental features might have influenced such high similarity. This agrees with the view of Aslan (2010) who reported that vegetation composition, topography, and human activities are the main influential factors on insect diversity.

\section{CONCLUSION}

It is advisable to move the hiking trails to slopes of Mount Sinai away from the basins (farshs) habitats. More studies are needed to assess the impact of hiking trails and associated human activities on other biodiversity elements in SKP.

\section{REFERENCES}

Aslan, E.G. (2010): Comparative diversity of Alticinae (Coleoptera: Chrysomelidae) between Çığlıkara and Dibek Nature Reserves in Antalya, TURKEY. Biological Bratislav journal. 65(2): 316-324.

Baha El Din, S.M. (2006): A Guide to the Reptiles and Amphibians of Egypt. American University in Cairo Press. 360 PP.

Barragan, F., Moreno, C.E., Escobar, F., Halffter, G. and Navarrete, D. (2011): Negative Impacts of Human Land Use on Dung Beetle. Functional Diversity. 6(3).

Berberich, G., Grumpe, A., Berberich, M., Klimetzek, D. and Wöhler C. (2016): Are red wood ants (Formica rufa-group) tectonic indicators? Astatistical approach. Ecological Indicators. 61:968979.

Bolton, B. (1994): Identification guide to the ant genera of the world. Library of congress cataloging in publication data. 1st edition. USA. 226 PP. 
Ciach, M., Maslanka, B., Krzus, A. and Wojas, T. (2017): Watch your step: insect mortality on hiking trails. Insect Conservation and Diversity. 10:129-140.

Fayed, A. and Shaltout, K. (2004): Conservation and sustainable use of Medicinal plants in arid and semi-arid eco-systems project, Egypt (GEF, UNDP) (project no: 12347/12348), Flora of Saint Catherine protectorate, final report. And Floristic Survey of the Mountainous Southern Sinai": Saint Katherine Protectorate, final report.

Fisher, J., Beames, L., Rangers, B.J., Rangers, N.N., Majer, J. and Heterick, B. (2014): Using ants to monitor changes within and surrounding the endangered Monsoon Vine Thickets of the tropical Dampier Peninsula, north Western Australia. Forest Ecology and Management. 318:78-90.

Fouda, M., Grainger, J., Salaama, W., Baha El Din, S., Paleczny, D., Zalat, S.M. and Gilbert, F. (2006): Management effectiveness evaluation of Egypt's Protected Area system. Unpublished report, Nature Conservation Sector, Egyptian Environmental Affairs Agency, Ministry of State for Environmental Affairs, Cairo.

Gollan, J.R., Lobry de Bruyn, L., Reid, N., Smith, D. and Wilkie, L. (2011): Can ants be used as ecological indicators of restoration progress in dynamic environments? A case study in a revegetated riparian zone. Ecological Indicators. 11:1517-1525.

Grainger, J. and Gilbert, F. (2008): Cultural and spiritual values of Protected Landscapes - the St Katherine case study. pp. 1-17 in Mallarach JM (ed) Cultural and Spiritual Values of Protected Landscapes and Seascapes. IUCN.

Gray, C. and Jongepier, E. (2008): Effect of human disturbance on arthropod diversity at Kirindy Forest, Western Madagascar. Topical biology assessment. 8:34-46.

Hoffmann, B.D. (2010): Using ants for rangeland monitoring: Global patterns in the responses of ant communities to grazing. Ecological Indicators. 10:105-111. 
Knight, R.L. and Cole, D.N. (1995): Wildlife responses to recreationists. In Knight, R.L. and Gutzwiller, K. (eds.), Wildlife and Recreationists: Coexistence Through Management And Research, pp. 51-69. Island Press, Washington, D.C.

Kwon, T. (2015): Ant assemblages along the Baekdudaegan Mountain Range in South Korea: Human roads and temperature niche. Journal of Asian-Pacific Biodiversity. 8:152-157.

Mader, H.J. (1984): Animal habitat isolation by roads and agricultural fields. Biological Conservation. 29: 81-96.

Majer, J.D. (1983): Ants: bioindicators of minesite rehabilitation, land-use and land conservation. Environmental Management. 7: 375-383.

Michelsen, O., McDevitt, J.E. and Coelho, C.R.V. (2014): A comparison of three methods to assess land use impacts on biodiversity in a case study of forestry plantations in New Zealand. International Journal of Life Cycle Assessment. 19:1214-1225.

Moustafa, A.A. and Klopatek, J.M. (1995): Vegetation and landforms of the Saint Catherine area, southern Sinai, Egypt. Journal of Arid Environments. 30: 385-395.

Pautasso, M. (2007): Scale dependence of the correlation between human population presence and vertebrate and plant species richness. Ecology Letters. 10:16-24.

Petraitis, P., Latham, R. and Niesenbaum, R. (1989): The maintenance of species diversity by disturbance. Quarterly Reviews in Biology. 64:393-418.

Queiroz, R.E., Ventura, M.A., Silva, L. (2014): Plant diversity in hiking trails crossing Natura 2000 areas in the Azores: implications for tourism and nature conservation. Biodiversity Conservation. $23: 1347-1365$.

Ramadan, A.A., Moustafa, A. A., Zaghloul, M.S., and Helmy, M.A. (2009): Conservation of Three Endangered Species at St. Catherine Protectorate, South Sinai, Egypt. CATRINA. 4 (1): 53- 64. 
Saint Katherine protectorate management plan (SKP-M.P.). (2003): Reference edition, pp 148.

Schmidt, F.A., Ribas, C.R., Schoereder, J.H. (2013): How predictable is the response of ant assemblages to natural forest recovery? Implications for their use as bioindicators. Ecological Indicators. 24: $158-166$.

Semida, F.M.M. (2006): Ungulate grazing impact on the local distribution of the rare species Rhopalomyia Tanaceticola karsh. (Diptera: Cecidomyiidae), In south Sinai ecosystem. Egyptian journal of biology, Bull. Ent. Soc. Egypt, 83: 51-60.

Shepherd, A. (2010): Conservation of the Sinai baton blue butterfly; the role of ants. Unpublished MSC. Thesis, University of Nottingham, p. 84.

Sinclair, A.R.E., Simon A.R. and Arcese, P. (2002): Protected Areas as Biodiversity Benchmarks for Human Impact: Agriculture and the Serengeti Avifauna. Biological Sciences. 269:2401-2405.

Zafra-Calvo, N., Rodriguez, M.A. and Lobo, J.M. (2010): Discerning the impact of human-mediated factors on biodiversity using bioclimatic envelope models and partial regression techniques. Diversity and Distributions. 16:300-309. 


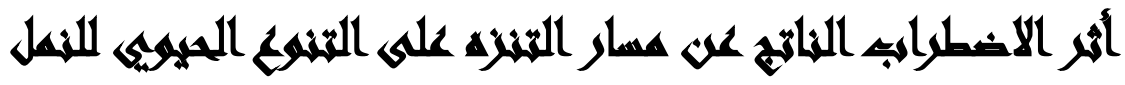

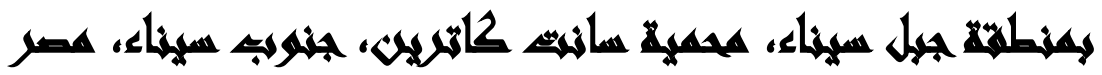

$[r]$

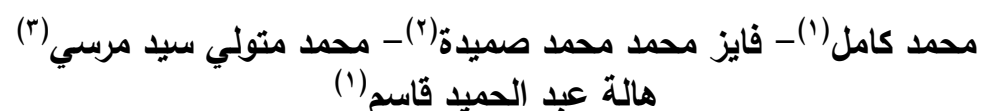

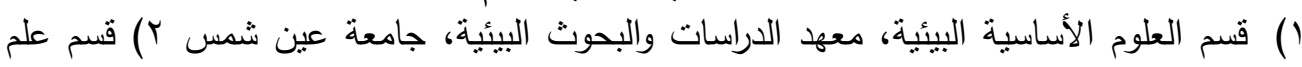
الحيوان، كلية العلوم، جامعة قناة السويس r) قسم النبات والميكروبيولوجي، كلية العلوم، جامعة

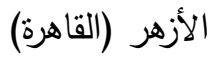

\section{المستخلي (1)}

تعتبر محمية سانت كاترين إحدى أهم مناطق التتوع الحيوي بمصر • وتعد السياحة والأنشطة

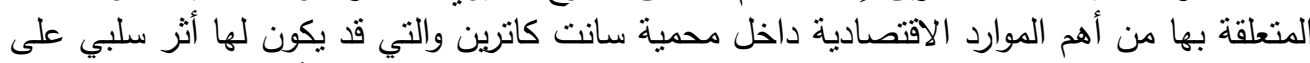

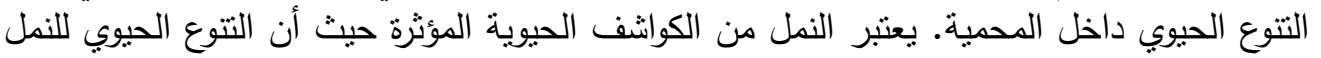

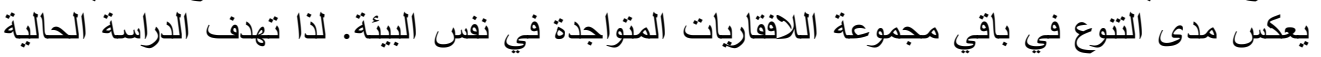

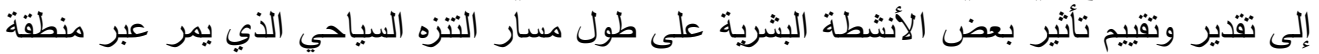

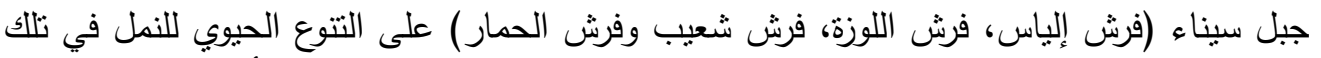

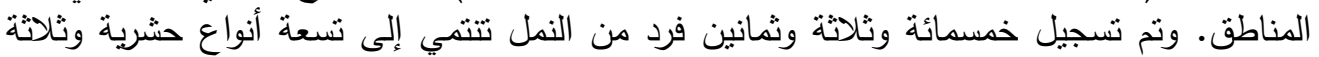

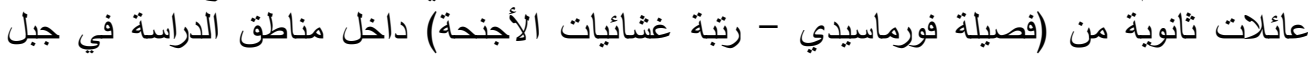

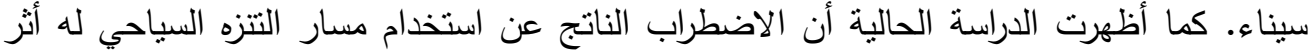

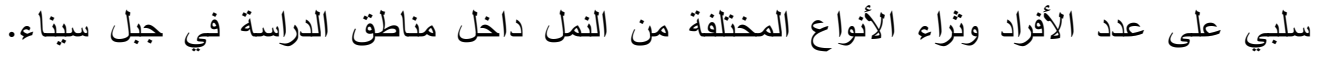

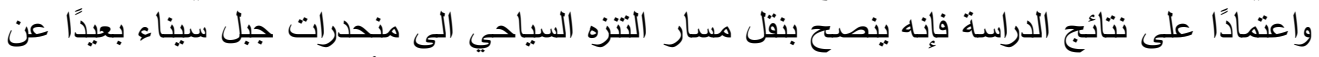
المواقع الحالية داخل الفروش. يجب إجراء المزيد من الدراسات لتقييم تأثنير مسارات التنزه والأنشطة البشرية المتعلقة بها على عناصر أخرى من عناصر التتوع الحيوي داخل محمية سانت كاترين. 